\title{
The Application of the Functions and the Roles of Tiga Batu Tungku to Solve Social Conflicts of Seram Society in Kamarian Village, Maluku Province, Indonesia
}

\author{
Marcus F. Pessireron \\ Andi Lolo \\ Tommy S.S. Eisenring \\ Department of Sociology, Universitas Negeri Makassar, \\ JIn. Bonto Langkasa Kampus Gunung Sari Baru, Makassar, South Sulawesi, Indonesia
}

\author{
Doi:10.5901/mjss.2017.v8n3p117
}

\begin{abstract}
Indonesia is an archipelago consisting of small and large islands stretching from Sabang to Merauke. The diversity of islands, religion, ethnicity, language, culture, and customs is a form of the socio-cultural systems that scattered throughout the islands of Indonesia. The differences among religions, tribes, and others sometimes create social conflicts among the citizens. However, the existence of Pancasila and the Constitution of 1945 are the National principle with the slogan "Bhinneka Tunggal Ika" which means that it is different, but it is still one. In addition, it is a state doctrine containing legal rules, norms, and values that set life's journey of Indonesian nation in the future. This slogan will be a tool to embed, bind, and unite the integrity of citizens. In addition, it can decrease the occurrence of social conflict. When there is dialectics, the social conflict which occurs in society and congregation, Tiga Batu Tungku as a local wisdom has a role of binding the unity of congregation at Kamarian village in Seram Island, Maluku Province. This local wisdom contains values, norms, religion, socio-culture, and customs which serve as social cohesion in reducing conflict. Values and norms are signs and rules to control human action and behavior in interacting with others. In this case, Tiga Batu Tungku has always played a role and function for a peaceful solution through dialogue to discuss and solve various social problems in society and internal part of Tiga Batu Tungku.
\end{abstract}

Keywords: Local wisdom, Tiga Batu Tungku, discussion, dialogue, values

\section{Introduction}

In general, the theory of conflict is a perspective in sociology that perceives society as a social system that consists of some parts or elements with different interests in which one component seeks to conquer, and the other components try to fulfill the maximum interests. The perspective of conflict theory about society is not entirely different from the view of structural functionalism theory because these two theories consider society as a system that consists of some parts. The difference between these theories depends on their assumptions about the different elements which form the society (Benard Raho, 2007). According to the theory of structural functionalism proposed by Rizer (2011), structural functionalism parts are united in a normal balance so that the society as a whole could run normally. Meanwhile, the elements of the theory of conflict have different interests so that they struggle to conquer each other to gain maximum profit.

The social conflicts that happen in Seram Island referred to this study is not the social conflicts which occur sporadically and physically like a mass riot that happens in Ambon, North Maluku, Posso, and others. The social conflicts intended in this study are focused on conflicts and differences of opinion, ideas, and concepts of the truth of knowledge. These social conflicts happen in the internal case in social institutions in Tiga Batu Tungku. The institutions consist of government institutions, traditional institutions, and Church institutions. The social conflicts are originated from a social activity conducted by the government. The government has announced to the society to carry out a clean country. 
However, only a few people who come to work on the predetermined day and hour. The Church performs the same thing. When the Christians are told to clean oil and clove plant owned by the Church, then they come out to work together. The questions that arise are why the society ignores the government, and why they are also more concerned to the Church. The government belongs to the society, and therefore they have to obey the government rules. Meanwhile, the Christians belong to the Lord because they belong to the Church. In this case, the customs are not in line with announcement conveyed by the Church and the government. Society and Christians are all indigenous people. Thus they belong to custom. The claims toward the society and the church that happen in the three social institutions create dialectics called social conflict.

The conflicts occurred in Tiga Batu Tungku are dialectical conflicts in the form of a complicated process, conceptual or social conflict, interconnection, and change in which the interpretation and contradiction create thinking method, that plays an important role in life (Outhwaite, 2008). It means that the dialectics or social conflicts which happen in the institutions of Tiga Batu Tungku are not to pursue a contestation toward the opponent who has conquered. However, the aim is to discuss and to resolve social problems by finding new ideas as proposed by Hegelisme in which He called them "Thesis, Antithesis, and Synthesis".

The process of peaceful reconciliation through discussion and dialogue are critical to maintaining the unity and integrity. Therefore, economic and religious development can be conducted for the sake of the welfare of society. Based on case studies in social institutions in Tiga Batu Tungku in Kamarian, the researcher problem is how the application of Tiga Batu Tungku roles solves various social problems in Kamarian, Maluku province.

\section{Method}

This research was qualitative research that applied a prospective case study approach. In collecting the data, the researchers collected data or information carefully, deeply, and thoroughly to obtain the description of the cases occurred in the social institutions of Tiga Batu Tungku in Kamarian, Seram. The data were obtained through two sources of data, namely documentation and informants. The technique of data collection was through in-depth interviews. The data were then analyzed using the technique of interactive analysis intended to look at the process of the application of Tiga Batu Tungku roles in solving social conflicts.

The research was located in Kamarian, Seram Island, in Maluku Province. 18 informants in this study were selected by using purposive random sampling. The types of data in this research were primary and secondary data. The primary data were in the form of discursive practices obtained directly from the field through interviews of the informants (Tiga Batu Tungku). The secondary data were in the form of non-discursive practices gained from the study of literature, books, scientific work, and other scientific information resources which are relevant to the research problem. The social conflict resolution occurs in social institutions of Tiga Batu Tungku in Kamrian, Maluku province.

\section{Results and Discussion}

\subsection{Dialectics in Social Institutions of Tiga Batu Tungku}

The view of Social Marxism is entirely called the dialectical materialism by his followers. It is called dialectic because it comes from the philosophy of Hegel about dialectics as a process of change. The process of dialectics is started from the Thesis (first position), then Antithesis (second position), and finally Synthesis (truth), then it will be the new Thesis continuing the process until finally, it reaches the absolute truth, and in the end it must also deal by negation in accordance with the new era. The social dialectics developed by Hegel is abstract in which the process according to Hegel is only in the ideals and thoughts. However, Marx reverses the concept. According to Marx, the thing which is reflected in the ideal is a material world which is reflected by the human mind, and then it is moved into thoughts. In other words, thoughts or ideals according to Marx are formed by the material or object. He reveals that human being must live first before he can think. Therefore, thoughts or ideals do not change history but a way to produce (Ramly, 2014).

The core of dialectical materialism can simply be described as follows. Marx took the two elements of the idea proposed by Hegel. The first element is the ideas about the conflict between the opposing aspects. The second is the ideas that can continue to grow endlessly. Hegel reveals that the dialectic applies in the abstract world. However, Marx asserts that the dialectical law applies in the material world. In accordance with the views of Engels in which he called it materialism, Marx states that in any object or situation there are opposing aspects, and it contradicts each other, and this is referred to as a contradiction. According to these views, the balance will be raised, and it is stated that the object or situation has been negated. In the development of Marx thought, he explains that contradiction and antagonism are social 
conflicts (Adisusilo Sutarjo, 2007).

The next conflict theory is put forward by Dahrendorf (1959), and it is called the theory of dialectic conflict. He reveals that the society is divided into two classes. The first is the class which has the authority (dominant). The second is the class which does not have the authority (subject). According to this theory, the society is integrated because there are interesting groups that dominantly control society at large (Dahrendorf, 1959). Social conflicts among the social groups above indicate that one group wants to control and dominate another group because each has the interest to be achieved. Human, individual, and group interest are in the concept of knowledge. According to, Foucault (1979) knowledge is inseparable from power because the modern power can access all aspects of social life in which human being performs the vested interests in the concept of knowledge and power. According to Foucault (1980), power is omnipresent, and it happens through the power of human knowledge in interaction (Foucault, 1980). Conflicts are caused by the power of knowledge owned by the society to interact by maintaining knowledge of the truth.

The social conflicts among social institutions of Tiga Batu Tungku consisting of government, indigenous organizations, and Church institutions can occur in Kamarian society in Seram Island. Social conflicts initially happen due to mutual claims on society. For examples, government argues that the society is owned by the government. Church institution claims that the Christians or society belong to God. It means that they belong to the Church. In addition, the traditional institutions denied the government and the Church that the announcement presented above is not true. They consider that all of societies and Christians are indigenous people because they belong to the traditional institutions. Another example is internal conflict between the customary chiefs who are the same time as head of government (King) in Kamrian in which they did dismissal of members of the custom without passing through a negotiation process of discussion and dialogue. The King as the dominant class has the internal power toward the members of custom who leads a class that does not have own authority. It is worth recognized that any conflict would have an adverse impact to the society. It is the destruction of fraternal relations of solidarity and unity among them. Social conflicts among social groups above indicate that one group wants to control and dominate another group because each has an interest to be achieved. Human, individual, and group interests are in the concept of knowledge and power.

Although dialectics or social conflicts have occurred among the social institutions of Tiga Batu Tungku, there is a power that really becomes a tool for binding the society namely religious, social, cultural, and customs values that unite them like brother and sister. It generally can be demonstrated by the relationships in Tiga Batu Tungku such as the relationship (pela gandong) between two communities (Islamic and Christian), culture of wariwaa relationship, Masohi, Badati, and Maano, (fishing together and sharing the results). They are the local wisdom which becomes a tool for binding society in maintaining social cohesion and reducing social conflicts in society. Values and norms will be a controller of the attitudes and actions of human behavior in interaction between individuals and societies.

\subsection{The Functions and the Roles of Tiga Batu Tungku in Solving Various Social Problems in Society}

Tiga Batu Tungku is a social institution that still exists in the society, and it is responsible for carrying out the functions and the role to serving the interests and welfare of society. Tiga Batu Tugku is shaped by society, Christians, and customs. In addition, it can also be stated that there is society, custom, and Christians in it. Therefore, Tiga Batu Tungku is started to be formed from the existing of society-Christians.

Tiga Batu Tungku consists of government agencies, indigenous organizations, and Church (religion) institutions. Social institutions are formed by the existing of society and Christians as a communion. These three institutions are formed in the social structure, and there are also the parts of working together in one system that is responsible for carrying out the functions and the role in society. For example, the government institution performs its functions and roles of responsibility for the public service to the Kamarian society, especially regarding to development activities conducted by the government both physical and non-physical development for the welfare of society.

Several government programs can successfully be implemented in Kamarian. Therefore, the main factor that determines the success is by maintaining mutual trust between the government and the society. For example, the society selects the King or village heads as the leaders and therefore, the King and his staff are entrusted to manage public money. Based on the trust as a joint capital, the governments and societies are partners in building a cooperative relationship. It means that any development that will be undertaken by government agencies will not succeed if it does not involve other agencies because in society various elements will be partners of government such as economics, education, religion, sociocultural (customs), and others. All of these fields are in the structure, and it is a working system in which in the system there are parts, and the parts are interconnected and related to the other part. It should keep in mind that each part is working to be responsible for his job, and does not need to be involved in interfering with work of others.

It can be demonstrated in Tiga Batu Tungku where the social dialectics happens between the institutional Church 
and the government that has been described in the introduction above. Actors sometimes play the case in the arena coming from the government, the customs, or the church side because they have special interests to be achieved. When the social conflicts have occurred, the ways that can be conducted is by reducing and weakening the social conflict. Tiga Batu Tungku plays a role and function properly by offering solutions so that the societies agree to sit at the table to negotiate and discuss together to solve the social problems. It refers to the idea revealed by Bakhtin (in Hwa Yol Jung, 1999) on dialogism or conception of dialogue. He states that dialogue marks the existential condition of humanity in which one human being with another has a bond. Humans exist only when they are communicating using dialogue, and when the dialogue ended, and then there is nothing left of human nature. We may use consensus depending on the types of cases that can be differentiated using social analysis of what is right.

Blau (1964) in (Rizer and Goodman, 2004) reveals that values are seen as similarities in the feelings that unite the collective level of individuals on the basis of interaction. Therefore, reducing and weakening the potential for social conflict can be performed using the values and norms of religious, socio-cultural, and custom that are generally used as a social cohesion in the society. According to Coser in (Sutaryo, 1992), this social cohesion can establish social institutions. In addition, it can also shape the actions or habits that can reduce tension, because the conflict cannot be channeled.

Watloly (2005) reveals that local wisdom of Tiga Batu Tungku is pela gandong (the meaning of the life of people with mutual caring and sharing), potong dikuku rasa didaging, ale (you), rasa beta (I) rasa, sagu salempeng di pata dua, masohi, badati, and maano. Therefore, in order to prevent conflicts, we should try to avoid not meddling in the affairs and work of others. In this way, the system will run and normally work without any interference or obstacles. Thus, social dialectics will not occur in a particular society at Tiga Batu Tungku itself. The system can be seen from Tiga Batu Tungku because the government agencies, traditional institutions, and church institutions have inseparable cooperation and social relations. For examples, when there is a job in which the Church's roofs are replaced, the traditional institutions and the governments are participating, and vice versa.

The customary institution is an important partner of the government, the society, and church institutions. The customary institutions still play its function and its role in helping the government, for example in development activities in the community such as roads and bridges development. They are invited to attend a meeting with the government in providing input and advice to support the success of development that is intended.

All social activities such as stiffened by custom have been described above. If we examine rationally and critically, Habermas considered that it is able to save mankind from ignorance and poverty. However, Mazhab Frankfurt in Sumaryono $E$ (1983) reveals that it is the source of evil in human civilization itself because people no longer have morals. It means that Frankfurt called the first generation experienced a crisis in modern human civilization because they do not have the moral grip. Therefore, it can be stated that social activities in the form of traditional rituals are irrelevant to be maintained and implemented. Traditional thinking is still existed in the society, but it has expired. In addition, it is tricking of error and ways of thinking that have long since had to be buried or abandoned. Our logic thinking creates some critical questions. One of the questions is whether the social problems of society can be answered by doing traditional social activities as described above or not. It actually might be solved according to how people think by truly understand social events namely the customs and culture. On the Contrary, rationally and critically we precisely do the social activities of Pasawari (prayer). In fact, it is simply not profitable but it is detrimental to some people who have been deep-thinking concept and very sturdy and difficult to remove or abandon the social activities. The Kamarian society has stuck with traditional thinking even though their lives have entered the world of modernity and the developed technology.

However, behaviors and the ways of thinking are not necessarily able to directly and easily remove. Instrumental rationality proposed by Habermas was used as a control tool for achieving the target as the ultimate goal. It is considered that critical and rational thinking cannot be separated from the way we build an original network system and social structure. For example, Honda engines logically could not work without gasoline, spark plugs, and others. The traditional and modern thinking are in a position to be in development, progress, and change from one system. There is still a traditional thinking, and there is also still a modern thinking in relation the balance thinking. Automatically, the relationship between the parts of the human biological system or the motor engine cannot be removed and separated since they are in the same system. If the system wants to be activated, then according to Parson the action in social interaction is not more important than the role status (the functions and the roles of individuals) that is used in the theory of social action.

Therefore, the role of each element in the system should receive full attention. It can be demonstrated by the Church institution in which it is one part of the structure that has different functions and roles with other institutions. However, the function and the role to be played by the components of Tiga Batu Tungku should have a clear purpose. It means that the purpose is very important because it will lead us to achieve the success together. The Church institution in this regard will be a partner of the government and traditional institutions in the society. Therefore, the Church cannot work alone. The Church as a religious social organization always involves the government and traditional institutions. The 
Church does not only appear physically of a building from one organization but the Church also serves as a living building of the fellowship of the Christians. The Church is called to the center of the world as a living body to serve the world. Therefore, in carrying out its duties, it does not play its function and role in one direction. This means that the community of the Church serves selflessly. It does not distinguish between social status, rich and poor, ethnic, religious, cultural customs. The church is a congregation, and the congregation is the Church. They are the body of the human biologically. Therefore, the Church is called as a system just like the theory of social action system developed by Parson. Therefore the Church as a religious social institution is involved in helping the governments and traditional institutions to jointly build their economy and the community of the church.

One of the Church's duties is to always pray for the government because the government is derived from God. For example, the church builds bell tower of the Church, replaces Church roofs, constructs terraces of the church, and builds meeting room. All development activities carried out by the Church are always supported the government both physically in the form of funding and others. The government, traditional institutions, and Church institutions are not only concentrating on physical development but also non-physical, especially fostering spirituality and morality of the people or society. For example, conducting religious lectures related to the use of illegal drugs, such as drugs, marijuana, HIV I AIDS, and others for the church community.

There are some research findings from case studies of the application of the functions and the roles of Tiga Batu Tungku in solving various social problems in Kamarian, Maluku Province. First, Based on the custom Tiga Batu Tungku consists of government, traditional institutions, and church institution. Educational institutions have been merged with government agencies because the teachers are government people working on behalf of foreign governments. Meanwhile, in other customary lands, Tiga Batu Tungku consists of government, educational institution, and Church institution. They still apply government Act No. 51979 so that the education element is inserted into Tiga Batu Tungku. Second, Tiga Batu Tungku is a local wisdom in Kamarian society that will be social cohesion to dampen social conflict in the society. Third, Tiga Batu Tungku is a laboratory development and peacekeeping in the dialectic. In addition, it is a place in educating ethics, morality, and character of the church society.

\section{Conclusion}

Government, customary, and Church institutions have to be united in maintaining a relationship of brotherhood, and unity. They should also continue to build social relationships with all parties in the society. Tiga Batu Tungku is a symbol of harmony and peacefulness of different social status, or different ideas and concepts of human knowledge. Actually, there is no higher and lower position in Tiga Batu Tungku. They are equally high and low position. With this concept of thinking, thus there is a social balance among them. It is necessary to explain that it is impossible when one stone will have a higher or lower position than the other stones. It means that in the end, panici that is placed on three stones as a symbol of the cooking will be skewed because there is one stone that has higher or lower position. Therefore, its position, function, and role should be generalized to create a social balance. Therefore, social conflicts between them do not arise.

Firstly, social dialectics, conflicts, and contradiction of Tiga Batu Tungku are social capital. It is not to destroy each other, but it is the process of strengthening the structure and social system so that the relationship among them will be more solid. It means that the society is health if it has integrative and harmony relationships. However, it also requires a conflict so that social balance in building a life together will be created. Social conflicts that occur in Tiga Batu Tungku are no a physical conflict, but the conflict is in the form of the opinion ideas, and concepts in maintaining the truth of knowledge. Tiga Batu Tungku together argued in defending their opinions. They do it not to dominate. However, it is a way to conquer the interlocutors with the rational evidence to bring an opponent to follow their thinking on the formation of concept and ideas as presented by Hegel's Thesis, Antithesis and Synthesis.

Secondly, dialectics or social conflict in Tiga Batu Tungku aims at uniting people from different churches. The differences are in the form of ideas and social status. They are the collective wealth in order to strengthen friendship and build a cooperative relationship between the three institutions especially on economic development activities and religious development and other social problems in the community of the church.

When dialectics happens in Tiga Batu Tungku, the solution that needs to be performed is negotiating, making dialogue and discussing. It depends on the type of problem. The system built in solving problem processes conducted by Tiga Batu Tungku is the approach of kinship through religion, culture, and customs. In religion, culture, and customs, some values and norms can bind together and become signposts to control the pattern of people's actions. It means that the values and norms should be able to become a social cohesion in reducing the conflicts for instance, the relationship of Pela and Gandong, Badati, Masohi, Wariwaan. They will be a sort of miniature as control tool called the signposts to regulate behavior and morality of the society. 


\section{References}

Adisusilo. Sutarjo. (2007). Sejarah Pemikiran Barat. Yogyakarta: Universitas Sanata Dharma.

Anonim. (1979). Truth and Power: Interview with Alessandro Fontana and Pasquale Pasquino in Michel Foucault: Power, Truth, Strategy, eds Morris et ala. Sydney: Feral Publications.

Benard Raho. (2007). Teori Sosiologi Modern. Jakarta. Prestasi Pustaka.

Foucault, Michel. (1980). Power/Knowledge; Selected Interviews and Other Writing. 1972-1977. New York: Pantheon Books.

George Rizer. (2011). Sosiologi Ilmu Pengetahuan Berparadigma Ganda. Jakarta: Raja Grafindo Persada.

Hwa, Yol Jung. (1999). (Bakhtin, Michail Mikhailovich). In The Cambridge Dictionary to Philosophy. Robert Audi, ed. 70-71 . London: Cambridge University Press.

Yapi, Watloly. (2005). Maluku Baru; Bangkitnya Mesin Eksistensi Anak Negeri. Yogyakarta: Kanisius.

Michel Foucault. (1979). Truth and Power: Interview with Alessandro Fontana and Pasquale Pasquino in Michel Foucault: Power, Truth, Strategy, eds Morris et ala. Sydney: Feral Publications.

Rizer, G., and Douglas, J. Goodman. (2004). Teori Sosiologi Modern. Jakarta: Prenada Media Group. See George Rizer. (2012). Teori Sosiologi: Dari Sosiologi Klasik Sampai Perkembangan terakhir Posmodern. Jakarta: Pustaka Pelajar

Ralf Dahrendorf. (1959). Class and Class Conflict in Idustrial Society. Stanford: Stanford University Press.

Ramly, Andi Muawiyah. (2014). Peta Pemikiran Karl Marx: Materialisme Dialektika \& Materialisme Historis. Yogyakarta: LKIS.

Sumaryono. E. (1993). Hermeneutika: sebuah Metode Filsafat. Yogyakarta: Kanisius.

Sutaryo. (2012). Dinamika Masyarakat Dalam Prespektif Konflik. Yogyakarta: FISIPO-Universitas Gajah Mada.

Rizer, G. and Douglas, J. Goodman. (2004). Teori Sosiologi Modern. Jakarta: Prenada Media Group. See George Rizer. (2012). Teori Sosiologi: Dari Sosiologi Klasik Sampai Perkembangan terakhir Posmodern. Jakarta: Pustaka Pelajar.

William, Outhwaite. (2008). Ensiklopedi; Pemikiran Sosial Modern, (2nd Ed). Jakarta: Perdana Media Group. 